\title{
MADĪNAT AL-ZAHRĀ', EL PARAÍSO Y LOS FATIMÍES ${ }^{1}$
}

\author{
MARIBEL FIERRO \\ CSIC, Madrid
}

\section{La construcción de Madīnat al-Zahrā'}

Madinat al-Zahrā' ${ }^{2}$ se eleva en un terreno situado en la falda de las últimas estribaciones de Sierra Morena en las proximidades de Córdoba, terreno que fue aterrazado para la construcción de la ciudad de 'Abd al-Raḥmān III. En la parte más elevada de ese terreno aterrazado se sitúa lo que se considera la zona residencial. Más abajo se encuentra la zona «oficial» con el salón de recepciones conocido como Salón de 'Abd al-Raḥmān III (llamado antes Salón Rico), mientras que en los niveles inferiores se ubica el resto de las edificaciones de la ciudad $^{3}$. El Salón forma parte de un conjunto que incluye un Pabellón

${ }^{1}$ Presento aquí una versión ampliada y modificada de una conferencia dada en el Departamento de Estudios Árabes del Instituto de Filología del CSIC el 23 de febrero de 2004. Esa conferencia nació a raíz de las lecturas hechas para mi biografía de 'Abd al-Rahmmān III que aparecerá dentro de la serie Makers of the Muslim world (Oneworld, en prensa) y, más en concreto, de una conversación con Julio Escalona. La asistencia a las IV Jornadas de Madīnat al-Zahrā' (celebradas en Córdoba en noviembre 2003) y las comunicaciones que allí se leyeron (en especial, la de María Antonia Martínez Núñez) sin duda influyeron en este artículo. Quiero agradecer a Carmen Barceló sus comentarios a la primera versión de este trabajo. Debo a Salvador Peña útiles sugerencias, y a él y a Miguel Vega la aclaración de varios puntos referentes a la numismática de época de 'Abd al-Raḥmān III.

2 Éste es el nombre con el que se hace referencia a la ciudad fundada por 'Abd al-Raḥmān III en las monedas allí acuñadas. El mismo nombre también aparece en fuentes literarias, junto con la forma al-Madīna al-Zahrā'. Véase al respecto Labarta, A. y Barceló, C., "Las fuentes árabes sobre al-Zahra': estado de la cuestión", Cuadernos de Madinat al-Zahrā' 1 (1987), 93-106, 95. Volveré luego sobre el asunto del nombre de la ciudad.

3 Véase una breve y clara presentación en Vallejo, A., "Madīnat al-Zahrā', capital y sede del Califato omeya andalusí", en El esplendor de los omeyas cordobeses. La civilización musulmana de Europa Occidental. Exposición en Madinat al-Zahrā', 3 de mayo a 30 de septiembre de 2001, Granada: El Legado Andalusí, 2001, 386-97. Del mismo autor puede verse "Madīnat al-Zahrā': el triunfo del estado islámico", Al-Andalus. Las artes islámicas en España, ed. Jerrilynn D. Dodds, Madrid: Ediciones El Viso, 1992, 27-40 (versión inglesa "Madinat al-Zahrā': the triumph of the Islamic state", in Al-Andalus: the art of Islamic Spain, ed. J. D. Dodds, New York: Metropolitan Museum of Art, 1992, 27-39) y "El proyecto urbanístico del estado califal: Madīnat al-Zahrā", en La arquitectura del Islam occidental, coord. Rafael López Guzmán, Barcelona: Lunwerg, 1995, 69-81.

Al-Qanțara XXV, 2 (2004) 299-327 
situado frente a él, y que parece una réplica suya a menor tamaño ${ }^{4}$, situado en el llamado Jardín Alto o Superior y rodeado de albercas. A un lado de este Jardín, se extiende otro, llamado Bajo o Inferior.

La construcción de Madīnat al-Zahrā' se inició hacia el año 329/940-1, poco después de haber tenido lugar la batalla de Simancas-Alhandega contra los cristianos. En esa batalla, la deslealtad de algunos de los comandantes del ŷund y de algunos señores de las regiones fronterizas favoreció una derrota musulmana en la que la vida del propio califa se vio en peligro y a raíz de la cual el ejemplar del Corán de 'Abd al-Raḥmān III quedó en manos de los cristianos. Hubo otras consecuencias:

al-Nāṣir quedó abrumado por su fracaso en esta campaña, sin paralelo en todo su anterior período $\mathrm{y}$, disgustado con su suerte, tenía confusos pensamientos y no era justo consigo, por lo que se le aconsejó distraer su preocupación con su mayor placer, la construcción. Dicen que se dedicó a ella de modo absorbente, fundando az-Zahrā' más abajo de Córdoba, poniendo en la holgura y majestad de sus edificios el descanso de su mente y olvidándose de lo demás, pues desde entonces dejó de guerrear personalmente ${ }^{5}$.

P. Chalmeta, en el estudio que ha dedicado a las repercusiones del episodio de Simancas-Alhandega, afirma que a partir de entonces el califa

no se fiará de sus tropas. El enemigo está dentro y quizás no fuera tan descabellado ver en Madīnat al-Zahrā' no una ciudad-palacio sino - cuando menos en parte - un alcázar reducto. Si 'Abd al-Raḥmān abandona el alcázar cordobés no es por afán constructivo ni porque le venga pequeño. El motivo real es muy distinto del «oficial»: ya no se siente seguro dentro de su capital. Esta inquietud y desconfianza se refleja en el extraordinario grosor de la doble muralla de bien labrados sillares que defiende la nueva ciudad. Y, sobre todo, el desusado colosal espesor de la cerca que ciñe y resguarda el alcázar califal. Sí, Madīnat al-Zahrā' es una ciudad fortaleza, protegida por unos muros cuya reciedumbre supera en mucho los de cualquier alcazaba o castillo... Insisto en ello, el ancho de los muros de la «ciudad del califa» no es debido a mero afán monumental, sino a razones estratégicas de defensa de lo que se considera el último bastión y reducto de la dinastía... Ahí estaba el reciente ejemplo de los Fatimíes salvándose de la rebelión del hombre del asno gracias a su creación de la residencia-refugio de Mahdiya ${ }^{6}$.

${ }^{4}$ Los paneles de ataurique sobre el zócalo que decoran el Salón también se encuentran en el Pabellón, aunque éste todavía debe ser objeto de estudio más pormenorizado.

5 Ibn Hayyān, de Córdoba, Crónica del califa 'Abdarrahmān III an-Nāșir entre los años 912 y 942 (al-Muqtabis V), trad. Viguera, M. J. y Corriente, F., Zaragoza, 1981, 327-8.

${ }^{6}$ Chalmeta, P., "Simancas y Alhandega", Hispania 36 (1976), 359-444, 397-8. 
Pero si ésta tal vez fuese la razón inicial de su construcción, ello no quiere decir que la ciudad no adoptase posteriormente otras funciones y significados. En el caso del Salón de 'Abd al-Rạ̣mān III, éste parece haber sido construido entre los años 342/953-4 y 345/ 956-7 y fue en esos años cuando se concibió la complejísima decoración vegetal que cubre sus paredes. La construcción del Salón, como ha demostrado Antonio Vallejo, supuso una importante remodelación del plan original de la ciudad.

\section{EI Salón de 'Abd al-Raḥmān III y su decoración vegetal}

La construcción del Salón coincide con la llegada al poder del califa fatimí al-Mu'izz (r. 341/953-365/975), el cual continuó la construcción de Șabra / Manșüriyya iniciada por su padre al-Manșūr en 335/946-7 7 , quien había logrado poner fin a la rebelión del líder beréber Abū Yazīd ${ }^{8}$. Éste, conocido como el «Hombre del Asno» (volveré luego sobre él), a punto había estado de poner fin a una dinastía que había llegado al poder fomentando las creencias escatológicas. Aunque hacia finales del gobierno de al-Mu'izz la idea de que la llegada del Mahdī o Mesías estaba próxima fue perdiendo fuerza, se mantuvo naturalmente la doctrina šī'í de que el califa fatimí poseía los poderes carismáticos del Profeta, podía hacer milagros, era infalible y estaba dotado de un conocimiento sobrenatural ${ }^{9}$. Un califa sunní como 'Abd al-Raḥmān III no lo tenía fácil a la hora de intentar superar a su rival desde el punto de vista político-religioso ${ }^{10}$. En este artículo propongo una posible forma en que lo hizo: la asimilación de su ciudad al $\mathrm{Pa}$ raíso.

\footnotetext{
${ }^{7}$ La ciudad palatina fatimí tenía forma circular, siguiendo el modelo del Bagdad abbasí, contrastando con la forma rectangular de Madīnat al-Zahrā', aunque una fuente tardía afirma que la forma original de la ciudad palatina de 'Abd al-Raḥmān III era también redonda (mudawwar), según testimonio recogido por el autor oriental al-Dahabī (m. 748/1348), Siyar a 'lām al-nubalä', varios editores, 23 vols., Beirut, 1985, VIII, 265-9, número 62

8 Sobre estos acontecimientos véanse Halm, Heinz, The Empire of the Mahdi: The Rise of the Fatimids, trad. M. Bonner, Leiden, 1996, 298-325, y Brett, Michael, The Rise of the Fatimids. The World of the Mediterranean and the Middle East in the tenth century $C E$, Leiden, 2001, 165-75.

${ }^{9}$ Halm, The Empire of the Mahdi, 350.

10 Véanse algunas de las formas en las que 'Abd al-Rahmān III lo intentó en Fierro, M., "Espacio sunní y espacio ši'‘'i”, El esplendor de los omeyas cordobeses, 168-177.
} 
Los estudios de Christian Ewert sobre la decoración vegetal ${ }^{11}$ que recubre las paredes del Salón de 'Abd al-Raḥmān III han puesto de manifiesto, entre otros, dos aspectos: 1) la enorme variedad de formas presentes en dicha decoración vegetal, pues se han podido documentar casi mil setecientos elementos y motivos dibujados; 2) la abundancia de composiciones asimétricas, en las que los responsables de la decoración revelan un insuperable sentido del equilibrio ornamental dictado por un eje central. La siguiente descripción dada por Ewert refleja la estructura básica de esa decoración y nos da idea de algunos de sus motivos:

Placas de una piedra calcárea muy blanda y de pocos centímetros de grueso forman un enchapado y sustituyen el material predilecto de la decoración arquitectónica andalusí, es decir el estuco. Anchos bordes sugieren el efecto de tapices. El ataurique parte generalmente del tallo o tronco central que se impone como eje de simetría. La trama es densísima. Los elementos, bien definidos por sus contornos cerrados, llenan perfectamente los espacios entre los fuertes tallos. Casi no dejan fondo... Los elementos básicos son hojas, muchas veces a manera de media palmeta o cáliz, frutos y flores. Dan origen a combinaciones de dos medias palmetas, «palmetas» compuestas de tres y más miembros y esporádicamente con la parte superior asimétrica... y, finalmente, a combinaciones asimétricas cuyo eje torcido sin embargo deforma y falsea un concepto básico simétrico... Otra pareja básica sumamente condensada es la compuesta por dos perlas anulares. En este caso también el fenómeno de multiplicación resulta casi ilimitado. De armonía perfecta es una combinación de cuatro perlas geométricamente inscrita en un cuadrado que sostiene, por ejemplo, una parte superior totalmente asimétrica con una hoja ondulada de acanto ${ }^{12}$.

M. Acién se ha planteado cuál pudo ser el significado y función de esos paneles decorativos en un estudio ${ }^{13}$ en el que empieza por señalar que la singularidad del Salón no reside en su concepción arquitectónica (el salón de la terraza superior de Madīnat al-Zahrā' tiene la misma planta) ni en la riqueza de los materiales constructivos (la solería de mármol blanco se encuentra en otras zonas de la ciudad). Esa singularidad reside en la exhuberante decoración parietal y, en concreto, en los paneles de ataurique sobre el zócalo del edificio, paneles

11 En este trabajo no voy a detenerme en consideraciones respecto a la procedencia de los motivos decorativos.

12 Ewert, Ch., "Elementos de la decoración vegetal del Salón Rico de Madīnat al-Zahrā': los tableros parietales", en Vallejo, Antonio (coord.), Madinat al-Zahrä'. El Salón de 'Abd al-Rahmān III, Córdoba, 1995, 41-58, 45.

13 "Materiales e hipótesis para una interpretación del Salón de 'Abd al-Raḥmān al-Nāṣir", en Vallejo (coord.), Madinat al-Zahrä', 177-195. 
que también se encuentran en el Pabellón frontero al salón (el que es una duplicación de éste a menor tamaño). El «simbolismo paradisíaco» del conjunto y la unidad de diseño del Salón y Jardín Alto como palacio celeste y Paraíso ya fueron puestos de manifiesto por Antonio Vallejo ${ }^{14}$. Pero, ¿cuál era el sentido de la decoración parietal del Salón de 'Abd al-Rahmān III?

Acién recoge la opinión funcional expresada por D.F. Ruggles, para quien el repetido uso de la vegetación, que se ha venido considerando como una referencia al Paraíso, también podría reflejar un significado político relacionado con el jardín y la ordenación del espacio cultivado. De hecho, señala Ruggles, no hay ninguna referencia textual explícita a una relación de los jardines andalusíes con el Pará so ${ }^{15}$. Acién, por su parte, precisa «que la alusión al paraíso, si bien se puede considerar subyacente en muchos investigadores, con respecto al sentido concreto de los paneles del salón de al-Nāșir, tan sólo la he podido encontrar apuntada en el comentario de L. Golvin a un tablero de mármol, que no procede precisamente del salón, sino del baño contiguo» ${ }^{16}$. Acién recuerda que F. Hernández Giménez demostró que esos paneles muestran «la imposición de una idea y un control absoluto de su ejecución» y que lo que sorprende es «que la idea impuesta y el control se llevaron a cabo sobre más de doscientos metros cuadrados, distribuidos en un número, como mínimo, de sesenta y cinco paneles, de los cuales no se ha resaltado lo suficiente... que son todos diferentes entre sí...», que, además, el hipotético eje de simetría que trazan los elementos decorativos «no es tal, puesto que ambas partes no tienen una correspondencia especular [la cursiva es mía]» y que además «lo que se representa son vegetales distintos en cada panel» ${ }^{17}$. Sigue diciendo Acién que en los estudios existentes subyace «la interpretación general de identificar la masiva presencia de ataurique con lo paradisíaco», de manera que

14 Acién Almansa, M., "Madīnat al-Zahrā' en el urbanismo musulmán", Cuadernos de Madinat al-Zahrä' 1 (1988), 11-26, 18, remite a A. Vallejo Triano. Véase de este último su artículo, "Madīnat al-Zahrā"” en Abdarrahman III y su época, Córdoba, 1991, 231-244, 240.

${ }^{15}$ Véase Ruggles, D. F., Gardens, Landscape, and vision in the Palaces of Islamic Spain, The Pennsylvania State University Press, 2000, 219.

${ }_{16} \mathrm{~V}$. en efecto Golvin, L., "Note sur un décor de marbre trouvé à Madīnat al-Zahrā"”, Al-Andalus XXV (1960), 188.

17 Acién, "Materiales e hipótesis", 185. 
toda la decoración del salón volvería a representar en el interior lo existente en el exterior, y la flora de los paneles tendría el mismo sentido que la vegetación real del jardín, a su vez, trasunto de la del paraiso [la cursiva es mía]. La enorme variedad de formas vegetales encontraría así un sentido, si bien no queda del todo aclarada su compartimentación en paneles de diversas medidas, a pesar de la obvia supeditación de éstos al conjunto arquitectónico ${ }^{18}$.

Acién plantea por ello otras hipótesis, como las posibles relaciones con el ceremonial cortesano, de manera que los distintos paneles podrían tener la función de indicar los sitios respectivos de personajes y grupos presentes ${ }^{19}$, y con la astrología, en concreto con ciertos pasajes del Picatrix. Las propuestas de Acién merecen ser tenidas en cuenta, especialmente la última ${ }^{20}$. Como se ha puesto de manifiesto en un estudio reciente, los recursos legitimadores de una dinastía suelen construirse sobre significados polivalentes que a menudo se entrecruzan y a veces convergen ${ }^{21}$, de manera que raramente se puede proponer una única interpretación.

\section{Los jardines del Paraíso a la luz de Corán 55: 46-78}

Pero me parece que no se ha fundamentado como debiera el simbolismo paradisíaco del conjunto del Salón de 'Abd al-Raḥmān III y los Jardines y que ese simbolismo no ha suscitado mayor interés, porque la asociación «palacio/jardín» con el Paraíso se considera un refe-

18 Acién, "Materiales e hipótesis", 186.

19 Ello entendiendo que el Salón era un Salón de recepciones. Sobre las recepciones en época califal véase Barceló, M., "El califa patente: el ceremonial omeya de Córdoba o la escenificación del poder", Estructuras y formas del poder en la historia, Salamanca, 1991, 51-71, reproducido en El salón de 'Abd al-Rahman III, 155-175, y El sol que salió por Occidente. Estudios sobre el estado omeya en al-Andalus, Universidad de Jaén, 1997, 137-162; trad. inglesa "The Manifest Caliph: Umayyad Ceremony in Córdoba, or the Staging of power", en M. Marin (ed.), The Formation of al-Andalus. Part 1: History and Society, Ashgate: Variorum, 1998 (The Formation of the Classical Islamic World, vol. 46), 425-56.

${ }^{20}$ En mi artículo "Bātinism in al-Andalus. Maslama b. Qāsim al-Qurțubī (d. 353/964), author of the Rutbat al-hakim and the Ghäyat al-hakim (Picatrix)", Studia Islamica 84 (1996), 87-112, hice referencia a esta hipótesis, pues la nueva autoría y la datación del Picatrix que propongo en dicho estudio establecen una vinculación precisa entre la composición de dicha obra y el reinado de "Abd al-Rahmān III.

${ }^{21}$ Véase el estudio sobre las monedas almohades llevado a cabo por Vega Martín, M., Peña Martín, S. y Feria García, M., El mensaje de las monedas almohades: numismática, traducción y pensamiento, Cuenca, 2002. 
rente general y vago, parte indisoluble de la actividad constructora palatina en el mundo islámico ${ }^{22} \mathrm{y}$, por lo tanto, poco explicativo. No me voy a extender en cosas ya sabidas, como que era razonable que la idea del jardín en tanto que Paraíso surgiera entre los árabes, habitantes de una tierra en la que el agua, los árboles y la sombra eran algo excepcional entre las rocas, las extensiones áridas y la vegetación agostada. Ni que no es de extrañar que los placeres del Paraíso se concibieran como aquellos de los que se gozan en jardines umbríos, teniendo que ver con la comida, la bebida, la unión sexual y la sociabilidad, todo ello aumentado y exento de imperfecciones. Los jardines son lugares deseables y deseados, y por tanto suelen estar rodeados de murallas para poder controlar el acceso a ellos, convirtiéndolos en lugares exclusivos, dedicados a la relajación y a la renovación física y espiritual:

Exploring the topic of images of Paradise in Islamic art raises a paradox: the closest parallel to the religious image of the heavenly garden is the secular paradise of the Islamic palace. Two interpretations are possible. The heaven of Islamic belief may represent the idea of a better life held by individuals living in arid and economically precarious societies; for them, a lush and well-watered garden represents all that the natural environment lacks. Alternatively, the builders of Islamic palaces may have had in mind the image of Heaven revealed in the Koran and created their earthly paradises following this concept. Both may be true, for the secular paradise of the Islamic palace can be traced back to pre-Islamic roots and is a reflection of the religious image. Palace courtyards with playing fountains and running streams have a long tradition in the Middle East and Mediterranean regions, while they also evoke the numerous Koranic descriptions of the heavenly garden ${ }^{23}$.

Los textos a los que voy a hacer referencia a continuación ayudan a precisar mejor esa interpretación «paradisíaca» y a dotarla de senti-

${ }^{22} \mathrm{La}$ forma en que la imagen religiosa del jardín celestial se tradujo a menudo en los paraísos seculares creados en los palacios de los gobernantes musulmanes ha sido objeto de numerosos estudios: véanse especialmente Brookes, J., Gardens of Paradise: the history and design of the Great Islamic Gardens, New York: New Amsterdam Books, 1987; Lehrmann, J., Earthly Paradise: Garden and courtyard in Islam, Berkeley/Los Angeles: University of California Press, 1980; MacDougall, E. y Ettinghausen, R. (eds.), The Islamic Garden, Washington, DC: Dumbarton Oaks Trustees for Harvard University, 1976 y más recientemente Blair, S. S. y J. M. Bloom (eds.), Images of paradise in Islamic art, Hanover (USA): Hood Museum of Art, Dartmouth College, 1991.

${ }^{23}$ Denny, Walter B., "Paradise attained: the Islamic palace", en Blair/Bloom (eds.), Images of paradise in Islamic art, 106. 
dos concretos, mostrando sus ventajas sobre otras posibles (aunque no desechables): explica no sólo la variedad, sino también la asimetría de las decoraciones parietales del Salón, da sentido a cómo pudieron surgir una serie de relatos en torno a Madīnat al-Zahrā', permite dar una nueva interpretación a la decoración en «verde y manganeso» de la cerámica allí producida, sugiere otro aspecto más del nombre por el que se conocía a dicha ciudad y puede ayudar también a comprender el por qué de una de las doctrinas atribuidas a Mundir b. Sa'īd al-Ballūṭì, cadí de 'Abd al-Rahmān III desde 339/950 hasta la muerte del califa. El silencio de las fuentes árabes sobre ese simbolismo paradisíaco puede ser puesto en relación, como veremos, con la anécdota de cómo ese mismo Mundir b. Sa'īd censuró la actividad constructora de 'Abd al-Rahmān III.

Es archisabido cómo en la concepción musulmana del Paraíso abundan las referencias a jardines, frutas, agua, pabellones y huríes ${ }^{24}$, elementos todos ellos ya presentes en el Corán. Valga una pequeña muestra de aleyas al respecto (la traducción es de Julio Cortés), sin olvidar que el jardín o los jardines se mencionan más de 130 veces en el Libro Sagrado de los musulmanes:

Anuncia la buena nueva a quienes creen y obran bien: tendrán Jardines por cuyos bajos fluyen arroyos. Siempre que les dé como sustento algụ́n fruto de ellos, dirán: «Esto es igual que lo que se nos ha dado antes.» Pero se les dará algo sólo parecido... (Corán 2: 25).

El Jardín será acercado a los que hayan temido a Dios, bien cerca (Corán 50: 31 , también en $26: 90$ y $81: 13$ )

... estarán entre azufaifos sin espinas y liños de acacias, en una extensa sombra, cerca de agua corriente y abundante fruta, inagotable y permitida, en lechos elevados (Corán 56, 28-34).

Los temerosos de Dios morarán entre jardines y arroyos, en una sede de verdad, junto a un potísimo Monarca ('inda malik muqtadir) (Corán, 54: 54-55)

Pero para la interpretación «paradisíaca» concreta que propongo del conjunto del Salón de 'Abd al-Raḥmān III con sus jardines son centrales los siguientes versículos del Corán:

24 Véanse al respecto los siguientes estudios: El-Saleh, Soubhi, La vie future selon le Coran, París, 1971; Smith, J. L. y Haddad, Y., The Islamic Understanding of Death and Resurrection, Albany, 1981; Blair/Bloom (eds.), Images of Paradise in Islamic art; al-Azmeh, A., "Rhetoric for the senses: a consideration of Muslim paradise narratives", Journal of Arabic Literature 26/3 (1995), 215-31. 
Para quien, en cambio, haya temido comparecer ante su Señor, habrá dos jardines

— ¿cuál, pues, de los beneficios de vuestro Señor negaréis? - ${ }^{25}$

con dos fuentes manando..

En ellos habrá dos especies de cada fruta...

Estarán reclinados en alfombras forradas de brocado.

Tendrán a su alcance la fruta de los dos jardines...

Estarán en ellos las de recatado mirar, no tocadas hasta entonces por hombre ni genio,...

cual jacinto y coral...

La recompensa del bien obrar ¿es otra que el mismo bien obrar?...

Además de esos dos, habrá otros dos jardines..

verdinegros..

con dos fuentes abundantes...

En ambos habrá frutas, palmeras y granados...

en ellos habrá buenas, bellas...

huríes, retiradas en sus pabellones...

no tocadas hasta entonces por hombre ni genio...

Reclinados en cojines verdes y bellas alfombras...

(Corán 55: 46-78).

En estos versos se establece una diferencia entre cuatro jardines del Paraíso, si bien el número en sí no hay que tomarlo al pie de la letra, siendo lo importante el hecho de que se establece una jerarquía entre ellos.

\section{Los jardines «superiores» del Paraíso: variedad y asimetría}

Hay dos jardines que tienen una cierta superioridad frente a los otros dos. Se caracterizan porque en ellos min kull fäkihatin zawŷāni, frase que Julio Cortés traduce como «dos especies de cada fruta». Aunque algunos exegetas la han entendido simplemente en el sentido de que cada fruto irá por pares, uno de los comentaristas más antiguos, al-Ṭabarī (m. 310/923), seguido por otros, especifica min kulli naw 'in min al-fäkihati darbāni, es decir, «de cada tipo de fruta habrá dos variedades» ${ }^{26}$. Pues bien, si hubiese que representar estos frutos

${ }^{25}$ Esta frase se repite prácticamente tras cada una de las líneas que siguen. La he omitido, indicando su presencia por medio de puntos suspensivos.

26 Al-Țabarī, Ŷămi 'al-bayān fí tafsìr al-Qur'ān, 30 vols., Bulaq, 1323-1329, XXVII, 86. Por su parte, el andalusí al-Qurtubī (m. 671/1272) interpreta la frase en el sentido de que cada fruta será de dos tipos y los dos serán dulces. Cita a continuación al Compañero 
del Paraíso que vienen a pares, pero son distintos, y las plantas o árboles de dónde proceden, ¿acaso una forma de hacerlo no sería una vegetación caracterizada por la asimetría que se ha detectado en las decoraciones parietales del Salón? Encuentra así sentido el hecho, señalado por Acién, de que las dos partes de cada panel no tengan una correspondencia especular.

Esos frutos del Paraíso estarán al alcance de la mano: quien estuviese en el Salón de 'Abd al-Rahmān III podría tocar los paneles con la mano al estar situados en las paredes. Señalaba Acién que «toda la decoración del salón volvería a representar en el interior lo existente en el exterior, y la flora de los paneles tendría el mismo sentido que la vegetación real del jardín, a su vez, trasunto de la del paraíso». Pero en los jardines de Madīnat al-Zahrā' cada especie vegetal no podría producir, como las del Paraíso, dos variedades distintas de la misma fruta al mismo tiempo. Por eso, la decoración asimétrica del Salón de 'Abd al-Raḥmān III lo que hacía en realidad era invertir el sentido propuesto por Acién: sus motivos vegetales eran los que verdaderamente constituían un «trasunto» de la flora del Paraíso, mientras que la flora del Jardín Superior de la ciudad no se salía, en cambio, de los límites impuestos por la naturaleza, por lo que debía ser «vista» en función de ese modelo paradisíaco representado en el Salón.

La imagen o imágenes del Paraíso que los musulmanes se hacen y se han hecho a lo largo de la historia no están basadas únicamente en el Corán, habiendo contribuido a ellas materiales muy diversos que han quedado recogidos en distintos géneros literarios como, entre otros, las compilaciones de Tradiciones del Profeta y sus Compañeros y Sucesores, tratados teológicos y obras de escatología. La búsqueda en estos textos nos ofrece claves para perfilar mejor cómo se ha intentado representar o sugerir el Paraíso en casos concretos. Tenemos la

del Profeta Ibn 'Abbās, diciendo que no hay en este mundo un árbol, ya sea dulce o amargo, que no se encuentre en el Paraíso, incluso la coloquíntida, aunque ésta será dulce en el otro mundo. Añade que se dice que cada fruta será de dos variedades, madura y seca, aunque esta última no desmerecerá de la otra en cuanto a la calidad y la bondad. Termina diciendo que la diferencia entre los dos jardines superiores y los dos inferiores será que éstos tendrán tan sólo un tipo de cada fruta, mientras que los primeros tendrán dos tipos: v. al-Ŷāmi 'li-ahkämm al-Qur'ān, 20 vols. en 10, vol. 17, Beirut, 1415/1995, 162-3. Agradezco a Luis Molina la información que me ha brindado sobre las obras de exégesis coránica que se ocupan de esta aleya a partir de los materiales reunidos en el CD-Rom Maktabat al-tafsìr wa-'ulüm al-Qur'ān (versión 1.5.) 
suerte de disponer de un texto compuesto por un autor andalusí que vivió en la primera mitad del s. III/IX en el que se recoge una detalladísima descripción del Paraíso. Me refiero a la obra de 'Abd al-Malik b. Habīb (m. 239/853) titulada Kitāb wașf al-firdaws ${ }^{27}$. Es éste un texto importantísimo que ya ha sido utilizado para una mejor comprensión de la iconografía de los mosaicos de la Mezquita omeya de Damasco que, como es sabido, ha sido interpretada como una visión del Paraíso ${ }^{28}$. Veamos algunas de las descripciones que contiene (el número que las acompaña corresponde al de los epígrafes en los que el editor dividió el texto árabe, división que ha sido seguida por Monferrer Sala en su traducción, que es la que recojo):

(24) ... Dijo 'Abd al-Malik: «Cuando llegue el día de la Resurrección y sean reemplazados los cielos y la tierra, tal como lo ha dicho Dios, Dios arrastrará el paraíso de un tirón, entonces quedarán extendidos todos los jardines que hay allí, hasta quedar lleno el abismo, que ocupaba el lugar en que estaban los cielos antes de que fuesen reemplazados; entre él y el trono no habrá cielo [alguno], salvo el trono que [ya] está hoy y, a la sazón, será el cielo del paraíso. Así lo dijo el Altísimo: El paraíso será acercado a los que hayan temido a Dios [Corán 26: 90] ... La tierra será reemplazada por una tierra de plata [Corán 3: 133] y sus gradas más altas [se remontarán] al trono, que será todo su cielo».

(25) ... El Profeta... ha dicho: «En el paraíso hay un palacio al que sólo entrará un profeta, un creyente [veraz: șiddiqq: el añadido es mío], un mártir o un imán justo ${ }^{29}$ 》.

[Este último es identificado con 'Umar b. al-Jațtāb, es decir, ese palacio está reservado para los profetas, los mártires y los dos primeros califas, Abū Bakr al-Ṣiddĩ y 'Umar, aunque por extensión se supone que en él entrarán los califas justos y bien guiados. Este añadido es mío].

(29) ... El Profeta... ha dicho: «En el Paraíso hay unas habitaciones desde cuyo interior se puede ver lo que hay fuera y desde su exterior lo que hay dentro, por lo finas y hermosas que son...

(41) Acerca de lo que Dios, Altísimo, ha dicho, en la otra vida habrá grados más elevados y una mayor distinción [Corán 17:21] y sobre [lo que también] ha dicho el Altísimo, ésos son creyentes de verdad. Gozarán de elevada categoría junto a su Señor, de perdón y generoso sustento [Corán 8:4], dijo 'Abd al-Malik: «Los

27 El texto árabe apareció publicado en Beirut, 1407/1987, edición reseñada por mí en Sharq al-Andalus 7 (1990), 243-4. El texto árabe ha sido traducido al español: 'Abd al-Malik b. Habīb, Kitāb wasf al-firdaws (La descripción del Paraíso), introducción, traducción y estudio por Monferrer Sala, J. P., Granada, 1997.

${ }^{28}$ Flood, F. B., The Great Mosque of Damascus. Studies on the making of an Umayyad visual culture, Leiden, 2001, 28-9.

${ }^{29}$ Es una referencia a Corán, 4:69. Véase también Ibn Habīb, Kitāb wașf al-firdaws, n. ${ }^{\circ} 50$. 
grados señalan los rangos y los méritos. Los grados del paraíso indican el mérito y el rango mediante los que Dios considera superiores a unos sobre otros en la medida en que hayan acatado [Sus leyes] en este mundo... La gente de cada grado, rango y mérito son compañeros. No es que sean compañeros cuando comen, beben y conviven, sino cuando se les agrupa [en función de] un mismo mérito...»

(55) Dijo 'Abd al-Malik: «... Referente al Jardín del Paraíso, al-firdaws son los viñedos y las uvas. Está en un monte alto del paraíso de donde brotan los ríos del paraíso. El Profeta... dijo: Pedid a Dios al-firdaws, es el centro mismo del paraíso, [el jardín] más elevado de donde fluyen los ríos del paraíso; la gente del paraíso oirá [allí] el traqueteo del trono».

(90) ... Las hojas del Paraíso son allí según los tipos de los frutos y de las clases de las aves; en el paraíso no hay [ninguna morada] que no se halle cubierta de ramas, inclusive de la variedad de la fruta y de las aves. Si una comunidad estuviese debajo de una de sus hojas los cubriría [a todos] de sombra. Las flores [forman] jardines, las hojas siempre están frescas...

(92) ... Dios no ha creado una [sola] flor (zahra) ni un [solo] color que no esté en él, a excepción del color negro. En el paraíso no hay [ninguna] morada que no esté cubierta por sus ramas, que producen adornos y túnicas, y de cuyo tallo manan dos fuentes...

(103) «Las ramas de los árboles del paraíso son de oro, las hojas son de zafiros y berilos, las palmas son como aquéllas. Sus hojas son cual las más hermosas túnicas que [jamás] haya visto alguien, sus frutos más suaves que la mantequilla y más dulces que la miel, en cada uno de cuyos árboles hay [toda] clase de frutos. Cada especie tiene un sabor distinto. Cuando a alguien le apetece un [fruto en concreto de entre todas] esas especies, se inclinan aquellas ramas en las que está dicho fruto que deseaba hasta que lo coge con su [propia] mano, [estando] tal como desee. [Tanto] si quiere estar de pie, como sentado o recostado, e [incluso] si lo desea [puede] abrir la boca para que [el fruto] entre en ella. Una vez haya cogido algún [fruto], Dios... creará [otro] mejor y más bueno que el anterior».

(242) «... Los frutos de este mundo tienen su época, luego se acaban, en cambio los del Paraíso nunca se agotan; los frutos de este mundo tienen quien los guarde, en cambio los del paraíso no». Acerca del dicho del Altísimo, cuyos frutos estarán al alcance de la mano, comentó al-Hasan: «Los alcanzarán [tanto si] están de pie, [como si] están sentados o acostados, como deseen». Sobre lo que ha dicho el Altísimo, sus frutos, al alcance, podrán ser cogidos fácilmente, señaló [al-Hasan]: «Estarán a su alcance, cogiéndolos del modo que quieran, cualquiera que sea [el fruto] que quieran [coger]». Acerca del dicho del Altísimo, siempre que se les dé como sustento algún fruto de ellos, dirán: «Esto es igual que lo que se nos ha dado antes». Pero se les dará algo sólo parecido [Corán, 2:25], [lo] mejor, sin que nada malo haya en él y asemejándose el último al primero en gusto y calidad, sin que nada malo haya en él».

En los ejemplos recogidos (y que son sólo una pequeña muestra del contenido del libro de Ibn Habīb) hay correspondencias claras con la situación topográfica de Madīnat al-Zahrā' y con algunas de sus ca- 
racterísticas. Tenemos la disposición del Paraíso como unos jardines (con tierra de plata: idea de blancura ${ }^{30}$ y brillo) que se extienden desde el cielo, donde está situado el Trono de Dios, hacia abajo, a modo de gradas o terrazas. Hay un Jardín que es el centro mismo del Paraíso, situado en un monte. La vegetación es abundantísima, variada y espesa ${ }^{31}$. Siempre hay frutos al alcance de la mano de quien los desee. En el Paraíso hay un palacio destinado a los profetas, los mártires y a los imames justos. Hay unas habitaciones desde cuyo interior se puede ver lo que hay fuera y desde su exterior lo que hay dentro (relación especular entre la flora del Jardín y la decoración vegetal del Salón). En el Paraíso los creyentes no están mezclados, hay una jerarquización según el rango y el mérito ${ }^{32}$.

En los textos en los que se hace referencia a Madīnat al-Zahrā' se cita con frecuencia al-saṭh al- 'alī que Labarta y Barceló traducen por «nivel superior», indicando que no está claro si se alude «a un nivel superior topográfico o arquitectónico. En él se localizan las salas de recepción y un espacio abierto» ${ }^{33}$. La raíz sṭh aparece una única vez en el Corán, en la azora 80, aleya 20. Tras describirse el Infierno y el Paraíso (versos 1-16), las siguientes aleyas mencionan la omnipotencia divina, pidiéndose a los hombres que consideren cómo Dios ha alzado el cielo, «cómo erigido los montes, cómo extendida (suțihat) la tierra». ¿No se podría ver en la denominación saṭ una referencia a esa aleya coránica? ¿No se utiliza acaso el término para denominar la parte de la ciudad en la que se ha allanado la tierra en la ladera del monte? Pero C. Barceló me hace ver que el término saț se utiliza también en la descripción del Alcázar cordobés, de manera que su uso en Madīnat al-Zahrā' no tendría mayor relevancia. Juan Pedro Monferrer me comunica asimismo que ese término no aparece en el Kitāb wasf al-firdaws.

\footnotetext{
${ }^{30}$ Esta idea de blancura se refleja en la historia legendaria de la esclava al-Zahrä' cuyo deseo de una ciudad que llevase su nombre habría motivado la construcción de Madīnat al-Zahrā': v. al respecto Marín, M., Mujeres en al-Andalus, Madrid, 2000, 79-80 con referencias.

31 ¿Hasta qué punto la utilización del llamado "cúfico florido" en las inscripciones de 'Abd al-Raḥmān III (v. Martínez Núñez, M. A., "Sentido de la epigrafía omeya de al-Andalus", El esplendor de los omeyas cordobeses, 408-17) no está también relacionado con el simbolismo paradisíaco?

${ }^{32}$ Véase también 'Abd al-Malik b. Habīb, Kitāb wașf al-firdaws, n. ${ }^{\text {os }} 37,41,178$.

${ }^{33}$ Labarta y Barceló, "Las fuentes árabes sobre al-Zahrā"”, 101.
} 


\section{Los «relámpagos» y los «mayordomos» del Paraíso}

Hemos visto antes cómo en la decoración parietal del Salón de 'Abd al-Raḥmān III aparecen «perlas». En la descripción coránica del Paraíso se mencionan con frecuencia joyas y perlas (Corán, 22:23, 37:49, 52:24, 56:23). Lo mismo ocurre en la Tradición, donde se dice, por ejemplo, que a los habitantes del Paraíso se les dará un alimento consistente en oro y perlas trituradas y donde se hace referencia a palacios hechos de perlas o de una sola perla de proporciones gigantescas ${ }^{34}$. Hay una famosa descripción de lo que algunos autores identifican como uno de los salones de Madīnat al-Zahrā' ${ }^{35}$ donde se menciona precisamente una perla y que recojo aquí en la versión del Dikr biläd al-Andalus:

En el alcázar construyó ['Abd al-Raḥmān III] un salón llamado Maŷlis al-jiläfa cuyos muros y techo eran de oro y mármol muy grueso, de color purísimo y de distintos tipos. En el centro de este prodigioso salón estaba la perla que le había regalado León, rey de Constantinopla, y sus tejas eran de oro y plata. En medio del salón había un gran estanque lleno de mercurio y a cada uno de los lados de la estancia se abrían ocho puertas con arcos de marfil y ébano guarnecidos de oro y diversas piedras preciosas que se apoyaban en columnas de mármol de colores y cristal puro. El sol, al atravesar esas puertas, bañaba con sus rayos el techo y las paredes del salón, que los reflejaban, formando así un resplandor deslumbrante (nūr ya'judu al-abșār). El soberano, cuando quería asustar a sus contertulios, hacía una seña a uno de sus esclavos y éste removía el mercurio, con lo que el salón se llenaba de una luz relampagueante que embargaba los corazones de los presentes (nūr ka-lama 'ān al-barq ya'judu bi-ŷamí al-qulüb), pues les parecía que la esta.cia daba vueltas mientras el mercurio estaba en movimiento. Unos dicen que el salón giraba para estar siempre frente al sol, pero otros afirman que estaba fijo alrededor del estanque. Ni en el Islam ni antes había hecho nadie algo similar, pero a él le fue posible por las grandes cantidades de mercurio de que disponía ${ }^{36}$.

34 Véase Flood, The Great Mosque of Damascus, 27-8. Véase también 'Abd al-Malik b. Habīb, Kitāb wasf al-firdaws, n. ${ }^{\text {os }} 28,38,40$.

${ }_{35}$ Labarta y Barceló, "Las fuentes árabes sobre al-Zahrā", 102, piensan, sin embargo, que se trataba en realidad de un Salón del Alcázar cordobés. Para la localización del Salón en Madīnat al-Zahrā', véase ahora Molina, L., "Sobre el estanque de mercurio de Medina Azahara", en este mismo número de Al-Qanțara.

${ }^{36}$ Edición y traducción de Molina, L., 2 vols., Madrid, 1983, texto árabe 164, trad. 174. En el apéndice se dan referencias a otras fuentes (ninguna anterior al s. XII) que narran la misma historia. Véanse también las referencias en Labarta y Barceló, "Las fuentes árabes sobre al-Zahrā'”, 102. 
Los elementos presentes en este relato se pueden interpretar como una forma de calcar aspectos centrales de la descripción del Paraíso. Uno de ellos es el número de puertas: las del Paraíso son también ocho ${ }^{37}$. Otro es la construcción con oro y plata ${ }^{38}$. Otro es la luz relampagueante que es una de las características en las que se insiste al hablar de lo que cada creyente encontrará al entrar en el Paraíso:

(128) ... entrará, hallando cojines alineados, puertas [perfectamente] dispuestas y tapices extendidos [por doquier], y [se quedará] mirando los cimientos de su construcción, pues he aquí que ha sido edificado sobre unas rocas de perlas [con una amalgama] de color[es] amarillo, verde, rojo y blanco; luego alzará la vista hacia el techo y si no fuera que Dios le hubiese dado capacidad, una luz le arrebataría la vista, pues ésta es cual el relámpago (barq)...

(47) ... Si alguno de los del paraíso alza la mirada, le deslumbrará un resplandor hasta casi cegarlo, y así exclamará: «¿Qué es esto?, pues, de cierto, no creo que en el paraíso haya relámpagos...»

La descripción del Salón en el que se hace referencia a la alberca o estanque de mercurio ha sido considerada generalmente por los investigadores como legendaria, habiéndose puesto de relieve posibles precedentes literarios ${ }^{39}$ y señalándose cómo se registra en fuentes tardías. Pero en esa descripción se habla también de tejas de oro y plata. Pues bien, se ha documentado la existencia de tejas vidriadas en los colores melado y blanco en las excavaciones de Madinat al-Zahrā' ${ }^{40}$. Aunque la descripción fuese una invención ${ }^{41}$, su punto de partida pudo ser el hecho de que se sabía que el referente concreto del Salón de 'Abd al-Raḥmān III era el Paraíso, de manera que esos autores tardíos que la pusieron en circulación acumularon elementos pertenecientes a ese mismo referente.

Lo mismo pudo ocurrir con el relato de la embajada cristiana a Madīnat al-Zahrā' recogido por el místico Muhyī l-dīn Ibn 'Arabī y analizado por F. de la Granja, en el que se narra lo siguiente:

37 'Abd al-Malik b. Habīb, Kitäb wașf al-firdaws, n. ${ }^{\text {s }} 14,17$.

${ }^{38}$ Ibid., n. ${ }^{\text {os }}$ 7, 32.

39 Véase Rubiera, M. J., La arquitectura en la literatura árabe, Madrid, 1981, 84-5, relato sobre el palacio del gobernante egipcio Jumarāwayh ibn Țulūn (segunda mitad s. III/X). Pero en ese relato la función y características del estanque de mercurio no tienen nada que ver con las del Salón andalusí.

40 Comunicación personal de Antonio Vallejo, a quien agradezco la información al respecto, así como a Manuel Acién Almansa.

${ }_{41}$ Véase la opinión crítica de al-Maqqarī en Nafh al-țîb, 8 vols., ed. 'Abbās, I., Beirut, 1968, I, 527-8 (debo esta referencia a Carmen Barceló). 
Llegados [los embajadores: el añadido es mío] a la puerta de [Madinat] al-Zahrā', el suelo estaba alfombrado con brocado, desde la puerta de la ciudad hasta el trono, de la misma impresionante manera. Había colocado en sitios especiales chambelanes, que parecían reyes, con vestidos de brocado y seda, sentados en sillones ornados.

Cuando veían a un chambelán, no dejaban de prosternarse ante él, creyendo que se trataba del Califa. Pero les decían: «Alzad vuestras cabezas: éste es sólo uno de sus esclavos» ${ }^{42}$.

F. de la Granja ya puso en su día de manifiesto los precedentes literarios, tanto populares como cultos, de este relato. Pero además es una historia que también se cuenta del Paraíso: el creyente llegará al Paraíso y confundirá a los ángeles y otros servidores de Dios, rodeados de esplendor y luz, con Dios mismo, por lo que se postrará de hinojos para adorarles hasta que éstos le sacarán de su error ${ }^{43}$.

\section{Los jardines verdinegros del Paraíso}

Hemos visto que en la azora 55 del Corán se mencionan dos jardines situados por debajo de los dos «superiores», lo cual parece indicar que estarán destinados a quienes no hayan merecido una recompensa tan elevada como la de los que disfrutan de los dos primeros jardines. Esos jardines «inferiores» son verdinegros (mudhämmatāni), color que explica al-Tabarī como que «parecerán negros por la intensidad de su verdor» (muswāddatāni min šiddati judrati-himā), es decir, tendrán también una abundante vegetación, con dos fuentes y en ellos habrá frutos, palmeras y granados. Por su parte, 'Abd al-Malik b. Habīb explica el término coránico como «verdes que, debido a su peso, tienden a hacerse negros» (n..$\left.^{\circ} 99\right)^{44}$.

Es sabido que la fundación de Madinat al-Zahrā' fue unida a la producción de un tipo especial de cerámica a la que se conoce como de "verde y manganeso»: sobre un fondo blanco, aparecen distintos motivos en verde, bordeados de negro. Entre esos motivos predominan los vegetales ${ }^{45}$. Esa cerámica, en la que predominan las formas

42 De la Granja, F., "A propósito de una embajada cristiana en la corte de 'Abd al-Raḥmān III", Al-Andalus XXXIX (1974), 391-406, 393.

${ }^{43^{\circ}}$ Ibn Habïb, Kitāb wasf al-firdaws, n. ${ }^{\circ} 129,245$.

44 Véase también Kitāb wasf al-firdaws, n. ${ }^{\circ} 229$, final.

45 Véase Escudero Aranda, J., "La cerámica decorada en 'verde y manganeso' de Madīnat al-Zahrā"', Cuadernos de Madinat al-Zahrā' 2 (1988-90), 127-164. Una puesta 
abiertas (por lo que se ha considerado vajilla de mesa), parece haber sido objeto de regalo por parte del califa. M. Barceló ha vinculado el fondo blanco al color de los omeyas ${ }^{46}$, asociación seguida por Escudero, para quien

\begin{abstract}
la tricromía básica empleada en su ornamentación vendría a constituir un símbolo, o un emblema, de los omeyas andalusíes: el blanco como el color de la dinastía, el verde como el color del Profeta... y el negro la síntesis del poder, de la austeridad coránica y de la dignidad del trono califal. Es muy expresivo, en este sentido, el frecuente uso del lema al-mulk, que proclama «la identidad califal, el legítimo orden califal de la dinastía omeya» y de elementos florales como la palmeta, poseedora también de claras connotaciones simbólicas ${ }^{47}$.
\end{abstract}

Pero además de estos posibles referentes, ese color verde con borde negro puede vincularse también a los jardines verdinegros de los que se habla en Corán 55. Y no hay que olvidar que el color verde es el color por antonomasia del Paraíso islámico (Corán 18:31, 55:76, 76:21), así como de los mártires ${ }^{48}$.

al día sobre lo que se sabe sobre dicha cerámica puede encontrarse en Bazzana, A., "La céramique verde e morado califale à Valence: problèmes morphologiques et stylistiques", IV Congresso Internacional. A Cerâmica medieval no Mediterrâneo Occidental, Lisboa, 1987, 349-58 y Fuertes Santos, M. C., La cerámica califal del yacimiento de Cercadilla, Córdoba, Junta de Andalucía: Consejería de Cultura, 2002, 150-2.

46 Barceló, M., "Al-Mulk, el verde y el blanco. La vajilla califal omeya de Madīnat al-Zahrā'”, La cerámica altomedieval en el sur de al-Andalus, Granada, 1993, 291-9; reproducido en $\mathrm{El}$ sol que salió por Occidente. Estudios sobre el estado omeya en al-Andalus, Universidad de Jaén, 1997, 187-194.

47 Escudero Aranda, J., "La cerámica califal de Madinat al-Zahrā”", El esplendor de los omeyas cordobeses, 398-407, 402, remitiendo a Roselló Bordoy, G., "La céramique verte et brune en al-Andalus du X au XIII siècles", Le vert et le brun. De Kairouan a Avignon, céramiques du X au XV siècle, Marsella, 1995, 105-8.

48 Véase 'Abd al-Malik b. Ḥabīb, Kitāb waș al-firdaws, n. ${ }^{\text {os }} 162,166,240,245$. Hay una conocida tradición que afirma que el hálito vital (nasam) de los mártires está en el buche de pájaros verdes, el hálito vital de los creyentes está en buches de pájaros blancos y el hálito vital de la gente del infierno está en buches de pájaros negros: v. Lucini, M., La escatología musulmana en al-Andalus. El Kitāb al-dajīra fi cilm al-dār al-ājira atribuido a Ibn al-'Arabi, Tesis Doctoral inédita, Universidad Autónoma de Madrid, 1989, 537. En el Kitäb wașf al-firdaws (n. ${ }^{\circ}$ 303) se recoge la siguiente variante: "Cuando vuestros hermanos cayeron víctimas en Uhud, sus espíritus fueron colocados en unos pájaros verdes que beben hasta hartarse de los ríos del paraíso, comen de sus frutos y se albergan en unos candiles de luz [que están] a la sombra del trono...”. 
Omeyas y fatimíes en la época de la construcción del Salón de 'Abd al-Raḥmān III

Hemos visto que el Salón de 'Abd al-Raḥmān III no fue construido hasta los años 342/953-4 y 345/956-7 y que su construcción supuso una importante remodelación del plan original de la ciudad.

Por esas fechas, en el año 344/955, el califa llevó a cabo también una remodelación de la administración ${ }^{49}$, que consistió en la creación de cuatro «departamentos» dirigidos cada uno por un visir distinto: un departamento estaba encargado de la correspondencia inter-administrativa; el segundo, de la correspondencia con las regiones fronterizas; el tercero, de la transmisión de órdenes y decretos, y el cuarto, de la supervisión de las quejas y los asuntos de los gobernados. Esta reforma tuvo lugar en el mismo año en que los fatimíes atacaron el puerto de Almería, causando gran destrucción. Si ese ataque fue visto como el preludio de una invasión fatimí a gran escala, ello pudo mover al califa a reforzar el control del territorio bajo su mando mediante dicha reforma administrativa. Pero ya a partir de la derrota del Hombre del Asno en el año 336/947, la amenaza representada por el califato fatimí había cobrado nuevas dimensiones. Pero veamos antes brevemente quién era ese Hombre del Asno ${ }^{50}$.

El beréber Zanāta (de la rama de los Ifran) Abū Yazīd Majlad b. Kaydād era un jāriŷí, partidario por tanto de la igualdad entre beréberes y árabes, del derecho a rechazar y deponer a los gobernantes injustos y del deber de nombrar como imám de la comunidad tan sólo al mejor y más piadoso de entre los musulmanes, incluso aunque se tratase de un esclavo negro, de manera que se negaba a la familia del Profeta la posesión de un carisma especial. Hacia el año 332/944, las tropas Zanāta del Hombre del Asno, así llamado por su montura (símbolo de humildad), empezaron a obtener victorias militares contra los fatimíes en el Norte de África, llegando a conquistar Qayrawān, donde se acuñó moneda a nombre de Abū Yazīd. Los círculos malikíes de la ciudad, aun oponiéndose a sus doctrinas, vieron en él una manera de librarse de los šīíies, considerados un peligro mayor. Abū Yazīd, sin embargo, no logró conquistar Mahdiyya,

49 V. Ibn 'Id̄ārī, al-Bayān al-mugrib, ed. Colin, G. S. y Lévi-Provençal, E., vol. 2, Leiden, 1948-51, 220.

$50 \mathrm{~V}$. las referencias bibliográficas recogidas en la nota 8. 
la ciudad-fortaleza construida por los fatimíes al comienzo de su reinado, ni tampoco Susa.

Por las mismas fechas, en 333/944-5, según Ibn 'Iḍārī, apareció en Lisboa un hombre que pretendía ser miembro de la familia del Profeta y que su madre Maryam era descendiente de Fāṭima. Se arrogó ser profeta y pretendió que el ángel Gabriel le visitaba. Dio a sus seguidores una serie de normas y leyes, entre ellas que se rasurasen la cabeza (una práctica que generalmente se atribuye a los jāriŷíes). Nada más se sabe de este personaje. 'Abd al-Raḥmān III ya había tenido que hacer frente a movimientos de tipo mesiánico exacerbados, sin duda, por el ejemplo fatimí, pues en el año 315/927 había intervenido para derrotar a otro falso profeta, un beréber llamado Hamīm b. Mann Allāh al-Muftarī que había aparecido en las cercanías de Tetuán ${ }^{51}$. Tanto el califa fatimí como el omeya tenían, pues, que hacer frente a rebeldes heréticos.

Cuando el califa fatimí Ismā‘īl al-Manșūr (r. 335/946-341/953), que sería así llamado precisamente por su victoria sobre el Hombre del Asno, accedió al trono no estaba nada claro que esa victoria fuese a ser posible, pero en el año 335/946 logró derrotar y poner en fuga a Abū Yazīd. Este último había enviado embajadas a Córdoba para reconocer al califa omeya con objeto de obtener su apoyo militar en la lucha contra los fatimíes ${ }^{52}$. Pero el califa andalusí se tomó demasiado tiempo en decidir qué hacer y cuando la flota omeya llegó a las costas de Ifrīqiya, Abū Yazīd ya había sido derrotado definitivamente (año 336/947).

Esa derrota fue transformada en una prueba de la legitimidad de la dinastía fatimí y de la verdad de su doctrina. Abū Yazīd fue presentado por los fatimíes como el Daŷȳāl, el Anticristo que causaría grandes trastornos antes de la aparición del Mesías o Mahdī, que le derrotaría. En tanto que identificado con la figura escatológica de al-Daŷȳāl, Abū Yazīd no era simplemente un rival que propugnaba un islam alternativo y que luchaba por el poder político. Era el Gran Enemigo, cuya derrota abría la vía para la consumación del destino divino. Al derrotarle, el califa al-Manșūr se convertía a su vez en una figura mesiánica, era quien

51 Fierro, M., La heterodoxia en al-Andalus durante el periodo omeya, Madrid, 1987, 128-9, 143.

52 Viguera, M. J., "Los Fatimíes de Ifrīqiya en el Kitāb al-ḥulla de Ibn al-Abbār de Valencia”, Sharq al-Andalus II (1985), 29-37. 
había triunfado sobre el Mal para inaugurar una nueva época en la que la dinastía fatimí gobernaría hasta el final de los días ${ }^{53}$.

Fue en ese contexto cuando al-Manșūr introdujo ciertas innovaciones. Ya se ha mencionado que impulsó la construcción de la ciudad de Șabra-Manșūriyya con su característica forma circular, a imitación del Bagdad 'abbasí ( $\mathrm{y}$ a diferencia de la forma rectangular de Madīnat al-Zahrā', aunque véase lo expuesto en la nota 7). Pero la innovación más visible fue la reforma de las monedas, con la aparición en ellas de tres círculos concéntricos alrededor de un campo central con una inscripción horizontal. Posteriormente, su sucesor al-Mu'izz (r. 341/953-365/975) introdujo cambios más radicales tanto en el diseño como en el contenido šî́í de la inscripción. El campo horizontal desapareció, siendo sustituido por un punto central rodeado por tres bandas concéntricas circulares que contenían una inscripción que rezaba: «No hay más dios que Dios, único, sin asociado; Muhammad es el enviado de Dios; y 'Alī b. Abī Ṭālib es el heredero del Enviado y el diputado (wazir) más excelente y marido de la Radiante y Pura» (al-zahrā' al-batūl). En el reverso se decía entre otras cosas: «El siervo de Dios Ma'add Abū Tamīm, el imām al-Mu'izz li-dīn Allāh, Príncipe de los Creyentes, revivificador de la sunna de Muhammad, señor de los enviados [por Dios], y heredero de la gloria de los imames bien guiados». Estas agresivas fórmulas šī'íes ("Alī como heredero del Profeta y su diputado más excelente y la mención a su esposa Fātima como la Radiante y Pura) sólo duraron dos años (de 341/952-3 a 343/954-5), reemplazadas por un tipo más moderado desde 343/ 954-5 hasta el final del reinado de al-Mu'izz en el que sólo se decía: «Y 'Alī es el heredero más excelente y el diputado de los mejores de entre los enviados [por Dios]» ${ }^{54}$.

Si la victoria sobre Abū Yazīd representaba la verdad y legitimidad de los fatimíes, ¿qué repercusiones tenía esa misma victoria para

53 Brett, The rise of the Fatimids, 170-1.

54 Walker, P. E., Exploring an Islamic Empire. Fatimid history and its sources, London: IB Tauris, 2002, 97, donde se dice: "Without an explanation of them in the other sources, whether these overt proclamations of Shi' $i$ belief had special significance remains unclear. What is most obvious in them is none the less completely in line with Fatimid doctrine both before and after their use on the coinage. Therefore, the main unanswered question is why al-Mu'izz decided to add them and also why he dropped them after such a brief run of only two years". No se establece ninguna relación con lo que estaba pasando en la zona omeya. 
la legitimidad omeya? El falso profeta en Lisboa (sobre el que tan poco sabemos) pudo servir para demostrar que los omeyas también triunfaban sobre el Mal. Pero creo que la remodelación de Madinat al-Zahrā', y más en concreto la simbología paradisíaca del conjunto del Salón y los jardines, fue la principal manera en que 'Abd al-Rahimān III decidió contrarrestar los beneficios obtenidos por los fatimíes con su victoria sobre el Hombre del Asno.

Uno de los aspectos de esa remodelación fue que en 336/947 (el mismo año en que Abū Yazīd, el Anticristo de los fatimíes, era derrotado) se trasladó la ceca de Córdoba a Madinnat al-Zahrā' ${ }^{55}$. De hecho, gracias a ese traslado sabemos a ciencia cierta que en esa época ése era el nombre de la ciudad de 'Abd al-Raḥmān III, pues en las monedas allí acuñadas aparece el nombre de Madīnat al-Zahrā' ${ }^{56}$. Puesto que la mención de Fātima en las monedas fatimíes con la fórmula de al-zahrä' al-batūl es posterior (época de al-Mu'izz), ¿decidió al-Mu'izz introducir esa fórmula porque el califa omeya estaba llamando a su ciudad con un nombre que podía entenderse como una referencia a la hija del Profeta? En cualquier caso, la decisión de 'Abd al-Rahmmān III de llamar a su ciudad con un nombre que evocaba a Fāțima debió estar motivada precisamente por el lugar que ésta ocupaba en la legitimación de los fatimíes (aunque el nombre por el que es conocida la dinastía no fue utilizado por ellos sino hasta fechas muy tardías) ${ }^{57}$ : por ejemplo, en el sermón oficial que acompañaba la oración del viernes en territorio fatimí se mencionaba al Profeta «Muhammad y a su familia, al Príncipe de los Creyentes 'Alī, a sus hijos al-Ḥasan y al-Ḥusayn, y a la resplandeciente $(z a h r a \bar{\prime}) \gg{ }^{58}$.

\footnotetext{
55 Véase Canto, A., "De la ceca de al-Andalus a la de Madīnat al-Zahrā"”, Cuadernos de Madinat al-Zahrā' 3 (1991), 111-19 (traducción inglesa "From the sikkat al-Andalus to the mint of Madīnat al-Zahrā'”, en Marín, M. (ed.), The Formation of al-Andalus. Part 1: History and society, Ashgate: Variorum, 1998, 329-345).

56 El viajero oriental y espía fatimí Ibn Hawqal, quien llegó a al-Andalus en el año $337 / 948$, se refiere a la ciudad palatina con el nombre de al-Zahrā', pero no está claro en su texto si la forma era "Madīnat al-Zahrā"” o "al-Madīna al-Zahrā"”: Kitāb șürat al-arḍ, ed. Kramers, J., Leiden, 1873 (Bibliotheca Geographorum Arabicorum II), 77-8; trad. española de Romaní Suay, M. J., Ibn Hawkal. Configuración del mundo (fragmentos alusivos al Magreb y España), Valencia, 1971, 64-5.

57 Véase al respecto mi estudio "On al-fâtimi and al-fạtịimyūn", Jerusalem Studies in Arabic and Islam 20 (1996), 130-161, 144-7.

${ }^{58}$ Halm, The empire of the Mahdi, 124, 272.
} 
El traslado de la ceca de Córdoba a Madīnat al-Zahrā' supuso también la introducción de innovaciones en las monedas omeyas, pues la leyenda de reverso se ordenó en tres líneas (ordenación que durará hasta 350/961), frente a las cuatro de la etapa anterior (321/933336/947) ${ }^{59}$. ¿Se trataba de una imitación de la reforma formal de las monedas fatimíes a base de tres círculos concéntricos introducida por al-Manșūr?

Las series emitidas en la ceca de Madīnat al-Zahrā' se caracterizan por una gran variedad y riqueza decorativa. Los motivos decorativos eran tanto geométricos como basados en una gran variedad de formas: lo que llama la atención precisamente de las emisiones del período 336/947-341/952 es la aparición de esa variada ornamentación vegetal y floral. Durante el período 316/928-329/940, los signos decorativos eran especialmente simples, predominando las formas geométricas. Entre 330/941-335/946, un elemento decorativo fijo fue introducido en el reverso de las monedas de plata con la repetición sistemática de una flor de ocho pétalos. El extraordinario desarrollo decorativo que se produce entre los años 336/947-341/952, repito siguiendo a A. Canto, coincide con el traslado de la ceca desde Córdoba a Madīnat al-Zahrā'. Las emisiones de los años 947, 948, 949-50 son las que muestran mayor variedad decorativa, y a partir de ese último año, se advierte una pequeña disminución de la variedad, que se agudiza en los últimos años del califato de 'Abd al-Raḥmān III, cuando las monedas se decoran con temas geométricos o no tienen decoración alguna. Es evidente que esa rica ornamentación vegetal y floral de las monedas se corresponde con el programa decorativo del Salón de 'Abd al-Rahmān III: aunque la construcción de éste se feche con posterioridad a los cambios operados en las monedas, ambos fenómenos están estrechamente unidos.

Al-Mu'izz llegó al poder en 341/953 y un año después (en 342/953) el gobernante midrarí de Siŷilmāsa, que hasta entonces había prestado obediencia al califa omeya de al-Andalus, se proclamó califa con el título de al-Šākir li-1lāh ${ }^{60}$. Según Ibn Hazm, en cartas enviadas por 'Abd al-Raḥmān III desde Madīnat al-Zahrā' que él vio personalmente, el califa omeya se titulaba $a l-q \bar{a}{ }^{\prime} i m ~ l i-l l a \bar{h} h^{61}$, título

59 En lo que sigue me baso en el estudio de Canto mencionado en la nota 55.

${ }^{60}$ Halm, The Empire of the Mahdi, 397-8.

61 Ibn Hazm, Naqt al- 'arūs, en Rasā'il Ibn Hazm al-Andalusī, 4 vols., ed. 'Abbās, I., Beirut, 1980-1, IV, 49 (en la edición de C. F. Seybold, trad. L. Seco de Lucena, Valencia, 
que no mencionan las crónicas y que tiene claras resonancias mesiánicas, habiendo siendo utilizado especialmente por los š̄'íes. El hecho de que un califa sunní como 'Abd al-Rahmān III se decidiese a adoptarlo y a utilizarlo nos revela otro aspecto de esa incesante rivalidad entre omeyas y fatimíes expresada en los símbolos de la legitimidad. Esa adopción bien pudo producirse una vez que la derrota del Hombre del Asno pareció confirmar y reforzar el papel mesiánico de la dinastía fatimí.

\section{al-Madīna al-zahrā', la ciudad resplandeciente o deslumbrante}

Una de las características más sobresalientes del Paraíso es su resplandor, del que ya hemos visto una manifestación al hablar de los «relámpagos». Veamos otros ejemplos tomados de 'Abd al-Malik b. Habỉb.

(45) ... El Profeta dijo... «La gente del Paraíso verá a la gente de los grados superiores del mismo modo que la estrella fulgurante (al-kawkab al-durri) se ve en el confin del firmamento».

(46) ... «Las gentes del Paraíso se verán recíprocamente en el paraíso como el astro oriental se ve desde el astro occidental...».

(150) ... «El de las estancias superiores contempla a todos los que están por debajo de él; su luz lo ilumina todo, al igual que el sol ilumina la tierra cuando sale [por la mañana]»

(229) ... su apariencia será [la de] una luz brillante (nūr sāti ${ }^{\circ}$ ), cuyos rayos serán cual los rayos del sol cuando sale [por la mañana] y como la estrella rutilante (al-kawkab al-durrī) y el día luminoso; los palacios serán altos... y de zafiro que irradiará su luz (yazharu nūru-hā); si no fuera porque [Dios] la ha puesto a su servicio, su vista quedaría cegada [a causa] de la intensidad de su fulgor y del ojo de sus gemas... ${ }^{62}$

Ya se ha mencionado que el nombre de Madīnat al-Zahrā' por el que se conoce a la ciudad de 'Abd al-Rahmmān III pudo ser una manifestación más de esa rivalidad con la dinastía fatimí de la que acabamos de ver varios ejemplos. En efecto, en la legitimidad fatimí, como

1974, 151-2/68, este título aparece como al-qā'im bi-llāh). En IV, 63, Ibn Hazm recoge, sin embargo, el título al-qã 'im bi-amr Alläh. Véase al respecto Fierro, M., "Sobre la adopción del título califal por ‘Abd al-Raḥmān III”, Sharq al-Andalus VI (1989), 33-42, 38-9.

62 Véanse también n. ${ }^{\text {os }} 10,33,45,47,48,229,248$. 
indica la propia denominación de la dinastía, ocupa un lugar central la figura de la hija del Profeta, Fāțima, a la que se da el apelativo de $a l$-zahrä ${ }^{\prime}{ }^{63}$. De todas maneras, la raíz $z h r$ se había utilizado para denominar otras construcciones omeyas ${ }^{64}$.

Pero si Madīnat al-Zahrā' se construyó como escenificación del Paraíso en la tierra ¿no pudo estar relacionado su nombre también con esa idea de resplandor? Lo que se cuenta de la alberca de mercurio y de los tejados de oro y plata iría en ese sentido. Y a ello tal vez se podría añadir lo que se sabe sobre la iluminación pública de la ciudad ${ }^{65}$. Los versos de Ibn Zaydūn sobre Madīnat al-Zahrā', en los que dicha ciudad es comparada con el Paraíso, ponen de relieve su brillo: «Aquellos palacios reales cuyos aposentos brillaban y en los que las veladas sombrías parecían auroras» (si bien esto no deja de ser un tópico en la descripción de los palacios, recuérdese aquello de «¿Qué castillos son aquellos? Altos son y relucían...»), pero se menciona además en esos mismos versos un edificio conocido como al-Kawkab (la estrella) ${ }^{66}$.

\section{La censura de Mundir b. Sa'īd}

Una de las anécdotas más conocidas sobre el califato de 'Abd al-Raḥmān III es la que narra la censura que el cadí y predicador de Córdoba, Mundir b. Sa'īd al-Ballūṭī (m. 355/966), hizo al califa por haber dejado de cumplir la oración del viernes durante algún tiempo al estar demasiado ocupado en la construcción de Madinat al-Zahrā' ${ }^{67}$. Mundir había sido nombrado cadí en 339/950 (predicador unos años antes) y ocupó el cargo hasta su muerte acaecida ya en época del califa al-Ḥakam II. Fue, pues, durante su cadiazgo cuando

63 Véanse las referencias recogidas en mi artículo "Espacio sunní, espacio ši`'í', 175.

64 Véase Rubiera, La arquitectura, 122-4 y 177-8.

65 Véase Escudero, "La cerámica califal", 405, remitiendo a Valdés, F., "Kalifale Lampen", Madrider Mitteilungen 25 (1984), 208-216. Pero A. Vallejo me dice que ésta es una interpretación forzada del uso de las lamparillas encontradas en Madinat al-Zahrā'.

${ }^{66}$ Rubiera, La arquitectura, 129; Pérès, H., La poésie andalouse en arabe classique au XIe siècle. Ses aspects généraux, ses principaux thèmes et sa valeur documentaire, $2 .^{\mathrm{a}}$ ed., París, 1953, 124-5 (debo esta última referencia a Carmen Barceló).

${ }^{67}$ Las fuentes que citan esa censura (con variantes) están recogidas por de Felipe, H., Identidad y onomástica de los beréberes de al-Andalus, Madrid, 1997, 210-2. 
se construyó el Salón de 'Abd al-Raḥmān III. La censura de Mundir se articuló en dos partes y se expresó en ambas mediante la utilización de citas coránicas. En primer lugar, citó Corán 26: 128-135:

\footnotetext{
¿Construís en cada colina un monumento para divertiros y hacéis construcciones esperando, quizá, ser inmortales? Cuando usáis de violencia lo hacéis sin piedad... Temo por vosotros el castigo de un día terrible.
}

Esta cita parece una recriminación por construir Madīnat al-Zahrā, pero en la anécdota se presenta como una admonición para que dicha construcción no aparte al califa de sus deberes religiosos. En segundo lugar, el cadí citó Corán 43: 33-35 al visitar el Salón de Madīnat al-Zahrā' (según algunas fuentes, al ver una cúpula cubierta por metales preciosos):

Si no hubiera sido por evitar que los hombres formaran una comunidad única, habríamos puesto en las casas de los que no creen en el Compasivo terrazas de plata y gradas de acceso, puertas y lechos en los que reclinarse, y lujo. Pero todo esto no es sino breve deleite de la vida de acá, en tanto que la otra vida, junto a tu Señor, será para los que le temen.

En este caso, parece claro que el mensaje que se quiere transmitir es que para el cadí era inadmisible el lujo y el derroche en los que había incurrido el califa y se puede incluso entender que parte de la censura fue porque el califa estaba mostrando en este mundo un lujo reservado a los creyentes en la otra vida.

He tenido oportunidad de indicar en otra ocasión ${ }^{68}$ que un predicador oficial en un ámbito sunní es efectivo si se puede decir de él que ese nombramiento oficial no le ha atado de pies y manos, es decir, si se le permite censurar al poder. Esa censura no sólo no es una amenaza para el gobernante, por muy atrevida que pueda aparecer, sino que lo que hace precisamente es fortalecer a ese gobernante. La autoridad religiosa del califa sunní consiste en actuar como garante y protector de la ley religiosa islámica (šarī $a$ ), cuya interpretación está en manos, fundamentalmente, de los expertos en saber religioso o ulemas y cuyo ámbito de aplicación se extiende a la persona misma del califa. Por tanto, un califa sunní sale reforzado si el ulema al que

68 V. Fierro, M., "La política religiosa de 'Abd al-Raḥmān III", Al-Qanțara XXV (2004), 119-156. 
ha nombrado predicador oficial dirige parte de sus sermones a recordarle al califa cuáles son las normas que debe obedecer y a censurarle cuando se aparta de esas normas. Sólo un buen califa, justo y piadoso, permitiría tales exhortaciones y censuras y el hecho de que éstas tengan lugar cierra el círculo: el califa es bueno, justo y piadoso. La censura al gobernante sunní lo legitima al tiempo, frente a lo que ocurre en un ámbito šī'í en el que nunca puede haber censura a un imām que es infalible.

Pero aun así, la censura no se formula de balde. No sabemos si la censura formulada por Mundir tuvo algún efecto en la materialidad de lo construido en Madinat al-Zahrä', pero bien pudo tenerla. En la variante de la anécdota en la que se menciona una cúpula de metales preciosos se dice que el califa la mandó rehacer de modo sencillo. Sabemos que Mundir $\mathrm{b}$. Sa'īd censuró la eliminación del nombre de 'Alī y de materiales relativos a él en algunas obras compuestas en al-Andalus durante el s. IV/X y parece que su reprobación frenó una práctica que derivaba del odio omeya al cuarto califa ortodoxo (el primo y yerno del califa, de quien los fatimíes se proclamaban descendientes y herederos), práctica que no podía ser aceptable en una comunidad sunní ${ }^{69}$. Bajo al-Hakam II fue la mezquita de Córdoba (ésa a la que su predecesor 'Abd al-Rahmān III había dejado de asistir) la que fue objeto de una decoración suntuosa. Me refiero a los famosos mosaicos del mihrāb, en los que nuevamente se puede ver el simbolismo paradisíaco, con raíces en la tradición constructiva de los omeyas de Damasco ${ }^{70}$, pero esta vez asociado no a una ciudad, sino a un edificio religioso. Tal vez como ocurrió con los fatimíes cuando tuvieron que ir arrinconando la propaganda mesiánica de los inicios de la dinastía, el segundo califa omeya también tuvo que rebajar la promesa de un Paraíso en la tierra, reconduciéndolo a su dimensión escatológica ${ }^{71}$.

Una de las doctrinas teológicas que se atribuyen a Mundir b. Sa'ĩd tiene que ver con la diferencia entre el Paraíso terrenal en el que vi-

69 Ibid.

${ }^{70} \mathrm{~V}$. las referencias reunidas en Fierro, M., "En torno a la decoración con mosaicos de las mezquitas omeyas", Homenaje al Prof. Jacinto Bosch Vila, 2 vols., Granada, 1991, I, 131-144. Entonces me inclinaba a considerar que fue 'Abd al-Rahmān III quien concibió la decoración del mịrāăb.

71 En este sentido iría el abandono del cúfico florido en época de al-Hakam II: v. Martínez Núñez, "Sentido de la epigrafia omeya de al-Andalus", 416. 
vieron Adán y Eva y el otro Paraíso, el eterno (ŷannat al-juld), pues nuestro cadí

\begin{abstract}
opinaba que el paraíso y el infierno han sido, sí, creados ya, sólo que el paraíso no es el mismo en que Adán y su mujer fueron instalados por Dios. Fundábase para ello en varias razones, una de las cuales era que, si hubiese sido el mismo paraíso eterno, no habrían comido del árbol con la esperanza de vivir eternamente. Decía también que en el paraíso eterno no cabe la mentira, y, sin embargo, el diablo mintió en él. Decía, por fin, que quien entra en el paraíso, no sale ya de él, $\mathrm{y}$, sin embargo, Adán y su mujer salieron del paraíso ${ }^{72}$.
\end{abstract}

La misma opinión habría tenido también su contemporáneo, el ulema Wahb b. Masarra (m. 346/957) ${ }^{73}$. Se trata de una doctrina que no había sido objeto de especial preocupación entre los musulmanes ${ }^{74} \mathrm{y}$ tal vez se podría ver en ella un reflejo de discusiones relativas a esa identificación de Madinat al-Zahrā' con el Paraíso que he planteado aquí. La comparación de un palacio con el Paraíso eterno (ŷannat al-juld) ya había sido hecha en al-Andalus por 'Ubaydīs b. Mahmmūd en relación a una de las construcciones de Ibn al-Šāliya:

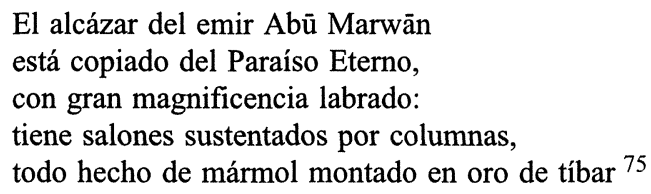

y siguió siendo hecha más tarde con las construcciones de Almanzor: «Votre palais d'al-'Āmiriya est comme le Paradis de Rị̣̂ān» ${ }^{76}$.

72 V. Fierro, Heterodoxia, 141, citando la traducción de M. Asín Palacios.

73 Ibid., 139, nota 52.

74 Véase van Ess, J., Theologie und Gesellschaft im 2. und 3. Jahrhundert Hidschra. Eine Geschichte des religiösen Denkens im frühen Islam, vol. IV, Berlin/New York, 1997, 550-4 (en 553, referencia a la doctrina de Mundir b. Sa'îid).

${ }^{75}$ Ibn Hayyān, Muqtabis, ed. Antuña, M. M., París, 1937, 11. La traducción es de Terés, E., "“Ubaydīs ibn Maḥmūd y Lubb ibn al-Šãliya, poetas de Šumuntān (Jaén)", Al-Andalus XLI (1976), 87-119, 113.

${ }^{76}$ Blachère, R., "Un pionnier de la culture arabe orientale en Espagne au Xe siècle: Șā‘id de Bagdad”, Hespéris X (1930), 16-36, 30. Riḍwān es el guardián del Paraíso: v. EI2, s.v. 


\section{A modo de conclusión}

Como he dicho antes, 'Abd al-Raḥmān III no lo tenía fácil a la hora de intentar superar a un rival, el califa fatimí, que se arrogaba unos poderes que el omeya, en tanto que califa sunní, no podía pretender tener. Pero lo que sí podía hacer era enfatizar determinados aspectos que formaban parte de la tradición sunní. Uno de ellos es que el califa asegura la salvación ${ }^{77}$. Y si lo hace, ¿no es como si el Paraíso ya existiese en este mundo, especialmente allí donde reside el califa?

El conjunto de Salón y Jardines que 'Abd al-Raḥmān III decidió construir en el terreno aterrazado de Madīnat al-Zahrā' pudo, por tanto, tener el siguiente mensaje: con la proclamación del califato en al-Andalus, es como si Dios hubiera extendido hacia abajo los jardines del Paraíso. Esos jardines tienen niveles o grados diferentes y el nivel más alto es aquél donde está el califa, quien sólo tiene por encima a Dios. El califa, el imām justo, es como si viviese ahora en esos dos Jardines superiores de los que habla la azora 55 del Corán. Por ello, la decoración del Salón sugiere esos frutos que vienen por pares, pero que no son iguales.

Los otros dos jardines están por debajo de él. Esos dos jardines inferiores se caracterizan por el verdor casi negro de su vegetación. La producción de cerámica en «verde y manganeso» en Madinat al-Zahrā' simbolizaba que el califa aseguraba a los que no habían sido elegidos para residir en el nivel superior la posibilidad de acceder a los otros jardines. La aleya coránica 76: 20 dice acerca del Paraíso: «Cuando se mira allá, no se ve sino delicia y suntuosidad» (wa-id $\bar{a}$ ra'ayta tamma ra'ayta na 'iman wa-mulkan kabìran). La cerámica producida en Madīnat al-Zahrā, con sus decoraciones vegetales y su leyenda al-mulk, proclamaba que esa «delicia y suntuosidad» ${ }^{78}$, prometida a los creyentes en la otra vida, estaba vinculada a una ciudad

\footnotetext{
77 Véase Crone, P. y Hinds, M., God's caliph: religious authority in the first centuries of Islam, Cambridge, 1986.

${ }^{78}$ Generalmente se considera que el término mulk hace referencia al poder califal. Ese término tiene un sentido negativo de acuerdo con el hadiz que reza que la verdadera jiläfa del Profeta duró tan sólo treinta años, durante el reinado de los califas ortodoxos, y que el califato posterior fue meramente realeza mundana (mulk) adquirida mediante usurpación. Véase este argumento en un texto contemporáneo del reinado de 'Abd al-Raḥmān III en Madelung, W., "A treatise on the imamate of the Fatimid caliph al-Mansūur bi-Allāh", Robinson, Chase (ed.), Texts, documents and artefacts. Islamic Studies in Honour of D. S. Richards, Leiden-Boston, 2003, 69-77, 76.
} 
resplandeciente como el Paraíso y al califa que la había construido, 'Abd al-Raḥmān III.

\title{
RESUMEN
}

Las aleyas coránicas sobre el Paraíso (y en especial Corán, 55: 46-78), así como el Kitäb wașfal-firdaws de 'Abd al-Malik b. Habỉb, nos permiten precisar mejor la interpretación «paradisíaca» de Madīnat al-Zahrā’ y dotarla de sentidos concretos, mostrando sus ventajas sobre otras posibles (aunque no desechables). Se explica así no sólo la variedad, sino también la asimetría, de las decoraciones parietales del Salón de 'Abd al-Rahmān III, se da sentido a cómo pudieron surgir una serie de relatos en torno a Madīnat al-Zahrā', se puede plantear una nueva interpretación de la decoración en «verde y manganeso» de la cerámica producida en la ciudad y se sugiere otro aspecto más del nombre por el que ésta fue conocida. También se puede establecer una relación con una de las doctrinas atribuidas a Mundir b. Sa'īd al-Ballūțī, cadí de 'Abd al-Raḥmän III desde 339/950 hasta la muerte del califa. El silencio de las fuentes árabes sobre ese simbolismo paradisíaco puede ser puesto en relación con la anécdota de cómo ese mismo Mundir b. Sa'īd censuró la actividad constructora de 'Abd al-Raḥmān III. Por último, Madīnat al-Zahrā' debe ser estudiada siempre dentro del contexto del enfrentamiento político-religioso con los Fatimíes y, más en concreto, con la situación surgida a partir de la derrota del «Hombre del Asno», presentado como figura escatológica (al-Daŷyâal) por los Fatimíes.

\begin{abstract}
Qur'ānic verses on Paradise (especially Qur'ān, 55: 46-78), as well as the Kitäb wasf al-firdaws by 'Abd al-Malik b. Habỉb, allow us to give specific meanings to the interpretation of Madinat al-Zahrā' as Paradise and to support it over other possible interpretations (although without necessarily eliminating the latter). On this basis, the variety and asymmetry of the wall decorations in the Hall of 'Abd al-Rahmān III are explained, as well as how certain narratives on Madīnat al-Zahrä' came into being. The «green and manganese» decoration of the pottery produced in the town is given a new meaning and some considerations are offered on the name given to the town. A relationship can be established between Madinat al-Zahrā' as Paradise and one of the doctrines attributed to Mundhir b. Sa'īd al-Ballūtị , judge of Abd al-Rahmān III from 339/950 until the death of the caliph. The silence of the Arab sources about this Paradisiac symbolism could be linked to the anecdote on how Mundhir b. Sa'îd censured 'Abd al-Rahmann III's building activity. Finally, Madīnat al-Zahrā' has to be studied within the context of the political and religious struggle with the Fatimids, and more specifically taking into account the situation after the defeat of the «Man of the Donkey», who was presented as an eschatological figure by the Fatimids.
\end{abstract}

